\title{
Centesimal and mineral composition of the fruit in Brazilian genotypes of feijoa (Acca sellowiana)
}

\author{
Cassandro Vidal Talamini do Amarante ${ }^{1}$, Alexandra Goede de Souza ${ }^{2}$, \\ Cristiano André Steffens ${ }^{1}$, Thalita Dal Toé Benincá ${ }^{3}$
}

\begin{abstract}
This research was carried out to evaluate centesimal [dry matter (DM), ash, and crude contents of proteins $(\mathrm{CP})$, fats $(\mathrm{CFt})$ and fiber $(\mathrm{CFb})]$ and mineral composition $(\mathrm{Ca}, \mathrm{Mg}, \mathrm{N}, \mathrm{P}, \mathrm{K}$, $\mathrm{Fe}, \mathrm{Zn}, \mathrm{Cu}$ and $\mathrm{Mn}$ ) of peel and flesh tissues of feijoa fruit (cultivars Alcântara, Mattos, Helena and Nonante, and accession 2316). The genotypes had, in the flesh, DM of 12.10-15.40\%, ash of $0.33-0.40 \%$, CP of $0.95-1.45 \%$, CFt of $0.56-1.72 \%$, and $\mathrm{CFb}$ of $1.39-2.43 \%$, and in the peel DM of $12.8-17.27 \%$, ash of $0.30-1.49 \%$, CP of $0.56-0.88 \%$, CFt of $0.57-0.90 \%$, and $\mathrm{CFb}$ of $2.54-3.98 \%$. The contents of $\mathrm{Ca}, \mathrm{Mg}, \mathrm{K}, \mathrm{N}$ and $\mathrm{P}$ in the peel were 96-116, 20-30, 1588-3635, 1096-1643 and $68-83 \mathrm{mg} \mathrm{kg}^{-1} \mathrm{FW}$, respectively, and in the flesh were 56-92, 17-29, 1358-2917, 2017-3384 and 255-374 $\mathrm{mg} \mathrm{kg}^{-1} \mathrm{FW}$, respectively. Among the micronutrients, Fe had the highest content in peel and flesh tissues $\left(\sim 3.5 \mathrm{mg} \mathrm{kg}^{-1} \mathrm{FW}\right)$. The results show that feijoa fruit represent a dietary source of $\mathrm{CP}, \mathrm{CFt}$ and $\mathrm{CFb}$, as well as of minerals, especially of $\mathrm{P}$ and $\mathrm{N}$ in the flesh, and of $\mathrm{K}$ and $\mathrm{Fe}$ in the peel and flesh tissues.
\end{abstract}

Index terms: Feijoa sellowiana, ash, fiber, fat, nutrient, protein.

\section{Composição centesimal e mineral dos frutos em genótipos brasileiros de goiabeira-serrana (Acca sellowiana)}

Corresponding author: cassandro.amarante@udesc.br

Received: April 25, 2019 Accepted: Octobre 08, 2019

Copyright: All the contents of this journal, except where otherwise noted, is licensed under a Creative Commons Attribution License.
Resumo - O objetivo deste trabalho foi avaliar a composição centesimal [matéria seca (MS), matéria mineral $(\mathrm{MM})$, proteína bruta $(\mathrm{PB})$, gordura bruta $(\mathrm{GB})$ e fibra bruta $(\mathrm{FB})]$ e mineral $(\mathrm{Ca}$, $\mathrm{Mg}, \mathrm{N}, \mathrm{P}, \mathrm{K}, \mathrm{Fe}, \mathrm{Zn}, \mathrm{Cu}$ e $\mathrm{Mn}$ ) nos tecidos da casca e da polpa dos frutos de goiabeira-serrana (cultivares Alcântara, Mattos, Helena e Nonante, e acesso 2316). Os genótipos apresentaram, na polpa, MS de $12,10-15,40 \%$, MM de $0,33-0,40 \%$, PB de $0,95-1,45 \%$, GB de $0,56-1,72 \%$ e FB de $1,39-2,43 \%$, e na casca MS de $12,80-17,27 \%$, MM de $0,30-1,49 \%$, PB de $0,56-0,88 \%$, GB de $0,57-0,97 \%$ e FB de 2,54-3,98\%. Os teores de $\mathrm{Ca}, \mathrm{Mg}, \mathrm{K}, \mathrm{N}$ e $\mathrm{P}$, na casca, foram de 96-116, 20-30, 1.588-3.635, 1.096-1.643 e 68-83 $\mathrm{mg} \mathrm{kg}^{-1}$ de matéria fresca (MF), respectivamente, e na polpa, de 56-92, 17-29, 1.358-2.917, 2.017-3.384 e 255-374 $\mathrm{mg} \mathrm{kg}^{-1} \mathrm{MF}$, respectivamente. Dentre os micronutrientes, o Fe apresentou os maiores teores na casca e na polpa $\left(\sim 3,5 \mathrm{mg} \mathrm{kg}^{-1} \mathrm{MF}\right)$. Os resultados mostram que a goiaba-serrana representa importante fonte de $\mathrm{PB}$, GB e FB na dieta humana, bem como de minerais, em especial de N e P na polpa, e de K e Fe na casca e na polpa. Termos para indexação: Feijoa sellowiana, matéria mineral, fibra, gordura, nutriente, proteína. 


\section{Introduction}

The daily consumption of fruits helps in the prevention of many diseases due to their nutritional and therapeutic value (SOERJOMATARAM et al., 2010). In addition to traditional fruits, there are many fruit of native species with great potential for human consumption, being required the characterization of their nutritional and functional properties, especially of traditionally unconsumed parts, such as skin and seeds. The content of nutrients and functional compounds may be higher in the skin or other non-consumed parts of the fruit than in the flesh (edible) tissue (IGNAT et al., 2011; AMARANTE et al., 2017a; AMARANTE et al., 2017b).

Feijoa [Acca sellowiana (Berg.) Burret, synonym Feijoa sellowiana Berg.] is a small evergreen tree belonging to the Myrtaceae family, native from southern of South America (south of Brasil, north of Argentina and western of Paraguai and Uruguai) (ARIOLI et al., 2018). Feijoa is cultivated in several regions of the world, and the fruit is appreciated for the unique flavor and aroma. In addition, feijoa fruit has antimicrobial, antitumoral, antinflammatory, antioxidant, gastroprotective and hepatoprotective action (WESTON, 2010; MONFORTE et al., 2014; AMARANTE et al., 2017a; AMARANTE et al., 2017b). Feijoa has great prospects for commercial cultivation, for fruit consumption in natura, as well as in processed forms of fleshs, ice creams, sweets and teas. The consumption of fruit skin, a traditionally non-edible part of feijoa fruit, can be an important source of nutrients, especially when it is included in differentiated recipes, justifying the characterization of its composition.

In Brasil, especially in the State of Santa Catarina, feijoa is cultivated in small areas and with seed-propagated trees. However, the quality of fruit from seed-propagated trees varies considerably from one seedling tree to the next. Vegetative propagation (from cutting, by grafting or by micropropagation) of superior genotypes of feijoa is essential to achieve uniform, high-quality fruit for developing local markets (THORP; BIELESKI, 2002). Nevertheless, some research work on plant breeding (for superior genotypes selection) (ARIOLI et al., 2018) and postharvest (AMARANTE et al., 2008; VELHO et al., 2011; AMARANTE et al., 2013; AMARANTE et al., 2017a) have been carried out in southern Brazil to promote the production and consumption of feijoa fruit with superior sensory quality. In 2007 and 2008, Santa Catarina launched the first Brazilian cultivars of feijoa (Alcântara, Mattos, Helena and Nonante) for commercial use (ARIOLI et al., 2018).

This study characterizes the centesimal and mineral composition of the skin and flesh tissues of the fruit in superior Brazilian genotypes of feijoa.

\section{Materials and methods}

Feijoa fruit were harvested from an orchard of Empresa de Pesquisa Agropecuária e Extensão Rural de Santa Catarina (EPAGRI), Experimental Station of São Joaquim, State of Santa Catarina (28 $18^{\circ}$ ' 40.02" $\mathrm{S}, 49^{\circ} 56^{\prime} 09.10^{\prime \prime} \mathrm{W}$ and altitude of $1,400 \mathrm{~m}$ ) planted in 2007. Fruit of uniform size and free of damage of four cultivars (Alcântara, Helena, Mattos and Nonante) and one accession (2316, with potential to be launched as a cultivar) were harvested in the middle portion of the tree canopy (from all quadrants), in 2012, 2013 and 2014. Ninety fruit of each cultivar were harvested at the commercial maturity, at the touch picking stage ('Alcântara' in the second fortnight of March, 'Mattos' in the first fortnight of April, 'Helena' and the accession 2316 in the second fortnight of April, and 'Nonante' in the first fortnight of May), and then immediately transported to the laboratory for analyses.

Fruit of all genotypes were harvested from trees cultivated in the same orchard and, therefore, subjected to the same nutrition and management conditions. The soil in the experimental area is a Humic Cambissol (Inceptisol), with the following physicochemical properties: clay $=$ $250 \mathrm{~g} \mathrm{dm}^{-3}$; organic matter $=69 \mathrm{~g} \mathrm{dm}^{-3} ; \mathrm{pH}$ in $\mathrm{H}_{2} \mathrm{O}=5.8$; $\mathrm{P}=4.2 \mathrm{mg} \mathrm{dm}^{-3} ; \mathrm{K}=2.51 \mathrm{mmol}_{\mathrm{c}} \mathrm{dm}^{-3} ; \mathrm{Ca}=17 \mathrm{mmol}_{\mathrm{c}}$ $\mathrm{dm}^{-3}$; and $\mathrm{Mg}=8 \mathrm{mmol}_{\mathrm{c}} \mathrm{dm}^{-3}$. Nitrogen fertilization along the experimental period (top-dressing at $30 \mathrm{~kg} \mathrm{ha}^{-1} \mathrm{~N}$ ) was carried out in November and January. Cultural and phytosanitary management followed the recommendations of Epagri for commercial production of feijoa (ARIOLI et al., 2018).

Fruit were separated into skin (external epidermis + hypodermic layers + external parenchyma, originated from the hypanthium) and flesh (internal epidermis + internal parenchyma + ovarian locus + fleshy tegument + placental bundle + seeds, originated from ovary development) tissues, and samples were then frozen in liquid nitrogen and stored at $-30{ }^{\circ} \mathrm{C}$ until analysis.

The analysis of the centesimal composition consisted in quantifying dry matter (DM), ash, crude protein $(\mathrm{CP})$, crude fat $(\mathrm{CFt})$ and crude fiber $(\mathrm{CFb})$. DM was assessed after drying the sample at $65^{\circ} \mathrm{C}$ until constant weight, and ash content by incineration of the sample in a muffle at $550{ }^{\circ} \mathrm{C} . \mathrm{CP}$ was evaluated by the Kjeldahl method (ASSOCIATION OF OFFICIALANALYTICAL CHEMISTRY - AOAC, 1995), after multiplying nitrogen content by 6.25 . CFt was assessed gravimetrically after extraction with chloroform and methanol (BLIGH; DYER, 1959), and CFb content was evaluated by the method proposed by Van Soest et al. (1981). Values of CP, CFt and $\mathrm{CFb}$ were expressed as percentage of fresh weight (FW).

Samples were assessed for total contents $\left(\mathrm{mg} \mathrm{kg}^{-1}\right.$ $\mathrm{FW})$ of the macronutrients calcium $(\mathrm{Ca})$, magnesium $(\mathrm{Mg})$, potassium $(\mathrm{K})$, nitrogen $(\mathrm{N})$ and phosphorus $(\mathrm{P})$, and of the micronutrients iron $(\mathrm{Fe})$, copper $(\mathrm{Cu})$, zinc $(\mathrm{Zn})$ 
and manganese (Mn). Nitrogen content was assessed by the Kjeldahl method, P content by spectrophotometry, $\mathrm{K}$ content by flame photometry, and the contents of $\mathrm{Ca}, \mathrm{Mg}, \mathrm{Fe}, \mathrm{Cu}, \mathrm{Zn}$ and $\mathrm{Mn}$ by atomic absorption spectrophotometry (TEDESCO et al., 1995).

The experiment followed a completely randomized design, with eight replications for centesimal analyses and ten replications for mineral analyses, each repetition consisting of five fruits. As data of all variables were consistent throughout the years, only mean data from the three years were subjected to analysis of variance. The genotypes were compared for the variables analyzed in each fruit tissue (skin and flesh) by Tukey's test $(\mathrm{P}<0.05)$, with the program SAS (SAS UNIVERSITY EDITION, 2017).

\section{Results and discussion}

The data of the centesimal composition showed, in all genotypes, higher $\mathrm{CFb}$ values in the skin and higher $\mathrm{CP}$ values in the flesh, without substantial difference between these tissues for the DM (Table 1).

Table 1 - Centesimal composition of the fruit (skin and flesh tissues) in superior Brazilian genotypes of feijoa (Acca sellowiana). Average values for fruit harvested in 2012, 2013 and 2014.

\begin{tabular}{|c|c|c|c|c|c|}
\hline Genotype & $\begin{array}{c}\text { Dry matter } \\
(\%)\end{array}$ & $\begin{array}{l}\text { Ash } \\
(\%)^{*}\end{array}$ & $\begin{array}{c}\text { Crude protein } \\
(\%)^{*}\end{array}$ & $\begin{array}{c}\text { Crude fat } \\
(\%)^{*}\end{array}$ & $\begin{array}{c}\text { Crude fibre } \\
(\%)^{*}\end{array}$ \\
\hline & & & Skin & & \\
\hline Alcântara & $12.8 \mathrm{~d}$ & $0.81 \mathrm{~b}$ & $0.88 \mathrm{a}$ & $0.57 \mathrm{c}$ & $2.5 \mathrm{~d}$ \\
\hline Helena & $15.8 \mathrm{~b}$ & $1.49 \mathrm{a}$ & $0.74 \mathrm{a}$ & $0.70 \mathrm{bc}$ & $4.0 \mathrm{a}$ \\
\hline Mattos & $16.1 \mathrm{~b}$ & $0.85 \mathrm{~b}$ & $0.77 \mathrm{a}$ & $0.69 \mathrm{bc}$ & $2.8 \mathrm{c}$ \\
\hline Nonante & $17.3 \mathrm{a}$ & $0.30 \mathrm{~d}$ & $0.79 \mathrm{a}$ & $0.97 \mathrm{a}$ & $3.9 \mathrm{a}$ \\
\hline Accession 2316 & $13.7 \mathrm{c}$ & $0.49 \mathrm{c}$ & $0.56 \mathrm{~b}$ & $0.73 \mathrm{a}$ & $3.1 \mathrm{~b}$ \\
\hline Mean & 15.1 & 0.79 & 0.75 & 0.73 & 3.3 \\
\hline \multirow[t]{2}{*}{ CV (\%) } & 11.2 & 53.1 & 17.0 & 19.5 & 18.3 \\
\hline & & & Flesh & & \\
\hline Alcântara & $12.1 \mathrm{~d}$ & $0.39 \mathrm{a}$ & $1.43 \mathrm{a}$ & $0.79 \mathrm{c}$ & $1.6 \mathrm{~b}$ \\
\hline Helena & $13.5 \mathrm{c}$ & $0.33 \mathrm{a}$ & $1.05 \mathrm{~b}$ & $0.74 \mathrm{c}$ & $1.4 \mathrm{c}$ \\
\hline Mattos & $15.4 \mathrm{a}$ & $0.37 \mathrm{a}$ & $0.95 \mathrm{~b}$ & $0.56 \mathrm{~d}$ & $1.7 \mathrm{~b}$ \\
\hline Nonante & $15.0 \mathrm{a}$ & $0.39 \mathrm{a}$ & $1.07 \mathrm{~b}$ & $1.06 \mathrm{~b}$ & $2.4 \mathrm{a}$ \\
\hline Accession 2316 & $14.3 \mathrm{~b}$ & $0.40 \mathrm{a}$ & $1.45 \mathrm{a}$ & $1.72 \mathrm{a}$ & $1.7 \mathrm{~b}$ \\
\hline Mean & 14.0 & 0.38 & 1.19 & 0.98 & 1.7 \\
\hline CV (\%) & 8.8 & 11.3 & 19.1 & 43.3 & 24.5 \\
\hline
\end{tabular}

*Values expressed in \% of FW. Values followed by the same letter within the columns are not different by Tukey's test ( $\mathrm{p}<0.05)$.

With the exception of 'Nonante', the skin had higher ash content than the flesh (especially 'Helena', with ash value $\sim 4.5$ higher in the skin than in the flesh tissue). With the exception of 'Mattos', CFt values were higher in flesh than in the skin.

The DM ranged from 12.80 to $17.27 \%$ in the skin, and from 12.10 to $15.40 \%$ in the flesh, depending on genotype (Table 1). These DM values are similar to those reported in the flesh of feijoa in Colombia (16.2\%) (LETERME et al., 2006), and in whole fruit in Spain (16.6\%) and New Zealand (11-16\%) (ROMERORODRIGUEZ et al., 1994). Monforte et al. (2014) reported lower DM in the flesh (19.4\%) than in the skin $(24.3 \%)$ of feijoa in Italy.

The ash content was different between genotypes only in the skin, with values varying from $0.30 \%$ ('Nonante') to $1.49 \%$ ('Helena'), while the flesh had average ash content of $0.38 \%$ (Table 1). In feijoa, ash contents (on a FW basis) of $0.20-0.40 \%$ were reported in whole fruits (ROMERO-RODRIGUEZ et al., 1994; MONFORTE et al., 2014), and of $0.80 \%$ in the flesh (LETERME et al., 2006).

The average CP content of all genotypes was $1.19 \%$ in the flesh and $0.75 \%$ in the skin (Table 1). The accession 2316 and 'Alcântara' had the highest CP contents in the flesh (respectively, $1.45 \%$ and $1.43 \%$ ), without difference for this attribute between the other genotypes (with $\mathrm{CP}$ contents varying from $0.95 \%$ to $1.07 \%$ ). Kinupp and Barros (2008) reported in the flesh of feijoa of wild occurrence in southern Brazil, much lower values of CP $(0.12 \%)$. This difference may be due to the genetic improvement of Brazilian genotypes studied, aiming superior quality attributes and higher flesh yield, differently from fruit of feijoa of wild occurrence in southern Brazil. In the skin, 
accession 2316 had the lowest CP content ( $0.56 \%$ ), while the other genotypes had similar CP content (varying from $0.74 \%$ to $0.88 \%$ ). There is no report in literature regarding $\mathrm{CP}$ content in the skin of feijoa fruit. CP contents in whole fruits of $0.5-1.0 \%$ and $1.1 \%$ (on a DW basis) have been reported in New Zealand and Spain, respectively (ROMERO-RODRIGUEZ et al., 1994).

As observed for $\mathrm{CP}$, on average of all genotypes, $\mathrm{CFt}$ contents were higher in the flesh $(0.98 \%)$ than in the skin $(0.73 \%)$ (Table 1$)$. In the flesh, CFt content ranged from $0.56 \%$ ('Mattos') to $1.72 \%$ (accession 2316 ). In the skin, CFt contents ranged from $0.69 \%$ ('Mattos') to $0.97 \%$ ('Nonante'). Romero-Rodriguez et al. (1994) reported CFt contents (on a DW basis) in whole fruits of $0.08 \%$ in Spain, and of $0.30-0.40 \%$ in New Zealand. The CFt contents in the flesh of feijoa are similar to those reported in other fruits, such as 'guabiroba' (Campomanesia adamantium) (0.55\%) (ALVES et al., 2013) and mango (Mangifera indica) (0.61\%) (MARQUES et al., 2010), and higher than those reported in blackberry (Rubus sp.) $(0.15-0.30 \%$, depending on genotype) (HIRSCH et al., 2012).

Feijoa fruit are rich source of fiber, with $\mathrm{CFb}$ values varying from $2.54 \%$ ('Alcântara') to 3.98\% ('Helena') in the skin, and from $1.39 \%$ ('Helena') to $2.43 \%$ ('Nonante') in the flesh (Table 1). The variation in $\mathrm{CFb}$ content between feijoa genotypes reflects genetic variability, as reported in cultivars of blackberry (HIRSCH et al., 2012). Romero-Rodriguez et al. (1994) reported in whole feijoa fruit, $\mathrm{CFb}$ contents (on a DW basis) of $3.8-4.3 \%$ and $5.0 \%$ in New Zealand and Spain, respectively. The $\mathrm{CFb}$ values in the flesh of feijoa genotypes (Table 1) are similar or superior to those of other fruits, such as orange $(0.8 \%)$, papaya $(1.0 \%)$, mango $(1.6 \%)$, and banana $(2.0 \%)$ (STORCK et al., 2013). Fruits of "umbu-cajá" (Spondias tuberosa) and "guabiroba" (Compomanesia xantocarpa), both native in Brazil, also have high contents of $\mathrm{CFb}$ (respectively, 1.36\% and 6.3\%) (VALLILO et al., 2008; SANTOS et al., 2010).

The contents of macronutrients in the peel and flesh tissues of the fruit were different between genotypes (Table 2). On average of all genotypes, the contents of $\mathrm{Mg}$ in both, skin and flesh tissues, were $\sim 22 \mathrm{mg} \mathrm{kg}^{-1} \mathrm{FW}$, while $\mathrm{Ca}$ and $\mathrm{K}$ contents were, respectively, 108 and $2868 \mathrm{mg}$ $\mathrm{kg}^{-1} \mathrm{FW}$ in the skin, and 81 and $2187 \mathrm{mg} \mathrm{kg}^{-1} \mathrm{FW}$ in the flesh (Table 2). The contents of $\mathrm{N}$ were $\sim 1.9$ times higher in the flesh $\left(2686 \mathrm{mg} \mathrm{kg}^{-1} \mathrm{FW}\right)$ than in the skin $(1427 \mathrm{mg}$ $\left.\mathrm{kg}^{-1} \mathrm{FW}\right)$. Similarly, the contents of $\mathrm{P}$ were $\sim 4.1$ times higher in the flesh (308 $\left.\mathrm{mg} \mathrm{kg}^{-1} \mathrm{DW}\right)$ than in the skin (75 $\mathrm{mg} \mathrm{kg}^{-1} \mathrm{DW}$ ).

Table 2 - Contents of macronutrients and micronutrients in the fruit (skin and flesh tissues; $\mathrm{mg} \mathrm{kg}^{-1} \mathrm{FW}$ ) in superior Brazilian genotypes of feijoa (Acca sellowiana). Average values for fruit harvested in 2012, 2013 and 2014.

\begin{tabular}{|c|c|c|c|c|c|c|c|c|c|}
\hline \multirow[b]{2}{*}{ Genotype } & \multicolumn{5}{|c|}{ Macronutrient } & \multicolumn{4}{|c|}{ Micronutrient } \\
\hline & $\mathrm{Ca}$ & $\mathrm{Mg}$ & $\mathrm{K}$ & $\mathrm{N}$ & $\mathrm{P}$ & $\mathrm{Fe}$ & $\mathrm{Zn}$ & $\mathrm{Cu}$ & $\mathrm{Mn}$ \\
\hline & & & & & Skin & & & & \\
\hline Alcântara & $116 \mathrm{a}$ & $20.6 \mathrm{~b}$ & $1588 \mathrm{c}$ & $1642 \mathrm{a}$ & $83 \mathrm{a}$ & $4.35 \mathrm{a}$ & $0.152 \mathrm{a}$ & $0.181 \mathrm{a}$ & $0.209 \mathrm{a}$ \\
\hline Helena & $108 \mathrm{~b}$ & $21.1 \mathrm{~b}$ & $3635 \mathrm{a}$ & $1408 \mathrm{~b}$ & $77 \mathrm{~b}$ & $3.34 \mathrm{c}$ & $0.150 \mathrm{a}$ & $0.129 \mathrm{c}$ & $0.161 \mathrm{~b}$ \\
\hline Mattos & $96 \mathrm{~b}$ & $20.6 \mathrm{~b}$ & $3411 \mathrm{ab}$ & $1643 \mathrm{a}$ & $70 \mathrm{c}$ & $3.02 \mathrm{~d}$ & $0.095 \mathrm{~b}$ & $0.142 \mathrm{~b}$ & $0.214 \mathrm{a}$ \\
\hline Nonante & $107 \mathrm{~b}$ & $20.3 \mathrm{~b}$ & $3042 \mathrm{bc}$ & $1349 b$ & $81 \mathrm{ab}$ & $3.86 \mathrm{~b}$ & $0.118 \mathrm{~b}$ & $0.149 \mathrm{~b}$ & $0.209 \mathrm{a}$ \\
\hline Accession 2316 & $114 \mathrm{a}$ & $30.1 \mathrm{a}$ & $2667 \mathrm{c}$ & $1096 \mathrm{c}$ & $68 \mathrm{c}$ & $2.74 \mathrm{e}$ & $0.111 \mathrm{~b}$ & $0.126 \mathrm{c}$ & $0.147 \mathrm{c}$ \\
\hline Mean & 108 & 22.6 & 2868 & 1427 & 75 & 3.46 & 0.125 & 0.145 & 0.188 \\
\hline \multirow[t]{2}{*}{ CV (\%) } & 18.6 & 16.1 & 17.1 & 24.7 & 10.3 & 17.1 & 27.4 & 14.6 & 16.4 \\
\hline & & & & & Flesh & & & & \\
\hline Alcântara & $92 \mathrm{a}$ & $20.7 \mathrm{~b}$ & $1916 \mathrm{~b}$ & $2017 \mathrm{~d}$ & $255 \mathrm{~d}$ & $4.62 \mathrm{a}$ & $0.162 \mathrm{c}$ & $0.190 \mathrm{a}$ & $0.236 \mathrm{a}$ \\
\hline Helena & $93 \mathrm{a}$ & $28.6 \mathrm{a}$ & $2143 \mathrm{~b}$ & $2940 \mathrm{~b}$ & $301 \mathrm{bc}$ & $2.96 \mathrm{c}$ & $0.194 \mathrm{~b}$ & $0.153 \mathrm{c}$ & $0.183 \mathrm{~d}$ \\
\hline Mattos & $85 \mathrm{~b}$ & $20.2 \mathrm{~b}$ & $1358 \mathrm{c}$ & $2448 \mathrm{c}$ & $281 \mathrm{~cd}$ & $3.10 \mathrm{c}$ & $0.172 \mathrm{c}$ & $0.167 \mathrm{~b}$ & $0.225 \mathrm{ab}$ \\
\hline Nonante & $56 \mathrm{~d}$ & $17.3 \mathrm{c}$ & $2603 \mathrm{a}$ & $3384 \mathrm{a}$ & $374 \mathrm{a}$ & $4.20 \mathrm{~b}$ & $0.129 \mathrm{~d}$ & $0.174 \mathrm{~b}$ & $0.219 b$ \\
\hline Accession 2316 & $78 \mathrm{c}$ & $23.3 \mathrm{~b}$ & $2917 \mathrm{a}$ & $2642 b c$ & $330 \mathrm{~b}$ & $2.97 \mathrm{c}$ & $0.222 \mathrm{a}$ & $0.171 \mathrm{~b}$ & $0.201 \mathrm{c}$ \\
\hline Mean & 81 & 22.0 & 2187 & 2686 & 308 & 3.57 & 0.176 & 0.171 & 0.213 \\
\hline CV $(\%)$ & 23.6 & 20.3 & 20.1 & 19.9 & 17.0 & 20.13 & 20.4 & 8.4 & 10.5 \\
\hline
\end{tabular}

Values followed by the same letter within the columns are not different by Tukey's test $(\mathrm{p}<0.05)$. 
The contents of $\mathrm{Ca}, \mathrm{Mg}, \mathrm{K}, \mathrm{N}$ and $\mathrm{P}$ differed among genotypes, with values in the skin of 96-116, 20.3-30.1, 1588-3635, 1096-1643, and 68-83 $\mathrm{mg} \mathrm{kg}^{-1} \mathrm{FW}$, respectively; and in the flesh of 56-93, 17.3-28.6, 13582917, 2017-3384, and 255-374 $\mathrm{mg} \mathrm{kg}^{-1} \mathrm{FW}$, respectively (Table 2). Fruit of all genotypes were harvested from trees cultivated in the same orchard (subjected to the same conditions of soil, climate and management). Therefore, differences of fruit mineral content between genotypes is due to genetic differences.

Kinupp and Barros (2008) reported similar contents of $\mathrm{Ca}\left(68 \mathrm{mg} \mathrm{kg}^{-1} \mathrm{FW}\right)$, higher contents of $\mathrm{Mg}$ (39 mg $\left.\mathrm{kg}^{-1} \mathrm{FW}\right)$, and lower contents of $\mathrm{K}\left(684 \mathrm{mg} \mathrm{kg}^{-1} \mathrm{FW}\right)$ and $\mathrm{P}(48 \mathrm{mg} \mathrm{kg}-1 \mathrm{FW})$ in the flesh (of fruit collected from wild populations of feijoa in Porto Alegre, State of Rio Grande do Sul, Brazil) than those contents shown in Table 2. Leterme et al. (2006) reported in Colombia contents of $\mathrm{Ca}, \mathrm{Mg}, \mathrm{P}$ and $\mathrm{K}$ in the flesh of feijoa fruit of $720,170,50$ and $1390 \mathrm{mg} \mathrm{kg}^{-1} \mathrm{DW}$, respectively. Romero-Rodriguez et al. (1994) reported in whole feijoa fruit (grown in New Zealand and Spain), contents of $\mathrm{Ca}, \mathrm{K}, \mathrm{Mg}$ and $\mathrm{P}$ of 40-144, 900-1700, 58-90 and 100-170 mg kg-1 DW, respectively. Beyhan et al. (2011) reported in whole fruit, contents of $\mathrm{N}, \mathrm{Ca}, \mathrm{Mg}, \mathrm{K}$ and $\mathrm{P}$ of 7200-14700, 33007500, 610-1030, 530-940, and 910-1040 $\mathrm{mg} \mathrm{kg}^{-1} \mathrm{DW}$, respectively, in different genotypes of feijoa cultivated in Turkey.

The contents of micronutrients in the peel and flesh tissues of the fruit were different between genotypes (Table 2). On average of all genotypes, the contents of $\mathrm{Fe}, \mathrm{Zn}$, $\mathrm{Cu}$ and $\mathrm{Mn}$ in the skin were 3.5, 0.125, 0.145, and 0.188 $\mathrm{mg} \mathrm{kg}^{-1} \mathrm{FW}$, respectively, while in the flesh were 3.6, $0.176,0.171$, and $0.213 \mathrm{mg} \mathrm{kg}^{-1} \mathrm{FW}$, respectively (Table 2). Among the micronutrients, Fe had the highest content in the peel and flesh tissues, confirming previous studies showing that feijoa fruit is a rich source of Fe (LETERME et al., 2006; SHRUTI BARROS, 2008; BEYHAN et al., 2011). Similar contents of $\mathrm{Fe}, \mathrm{Zn}$ and $\mathrm{Cu}$ (4.0, 0.22, and $0.16 \mathrm{mg} \mathrm{kg}^{-1} \mathrm{FW}$, respectively), and higher content of $\mathrm{Mn}\left(0.62 \mathrm{mg} \mathrm{kg}^{-1} \mathrm{FW}\right)$ were reported in the flesh, of fruit collected from wild populations of feijoa in southern Brazil (KINUPP; BARROS, 2008). Leterme et al. (2006) reported contents of $\mathrm{Fe}, \mathrm{Zn}, \mathrm{Cu}$ and $\mathrm{Mn}$ in the flesh of feijoa fruit in Colombia of 7.5, 1.5, 0.3, and $1.5 \mathrm{mg} \mathrm{kg}^{-1} \mathrm{DW}$, respectively. Romero-Rodriguez et al. (1994) reported in whole fruit of feijoa in New Zealand and Spain, contents of Fe, $\mathrm{Zn}, \mathrm{Cu}$ and $\mathrm{Mn}$ of 0.0-0.30, 0.05-0.10, 0.02-0.10 and 0.04-0.20 mg kg-1 DW, respectively. In feijoa genotypes cultivated in Turkey, the contents of $\mathrm{Fe}, \mathrm{Zn}, \mathrm{Cu}$ and $\mathrm{Mn}$ reported in whole fruit were 38-200, 2.90-7.30, 1.71-6.95 and $2.10-6.30 \mathrm{mg} \mathrm{kg}^{-1} \mathrm{DW}$, respectively (BEYHAN et al., 2011). Therefore, edaphic climatic conditions in different regions of feijoa cultivation affect fruit mineral content. There is no report in literature regarding micronutrient contents in the skin of feijoa.

This research is relevant, considering the limited data concerning the characterization of centesimal and mineral composition of feijoa fruit, especially for genotypes cultivated in southern Brazil. The results show substantial differences in terms of centesimal and mineral composition in the fruit between genotypes of feijoa. The differences for these attributes in the fruit reported by different authors might reflect distinct edaphoclimatic conditions, mineral nutrition and plant management in different cultivation areas, besides the genetic variability (BEYHAN et al., 2011; AMARANTE et al., 2013). In addition, this might reflect differences in terms of tissue sampling method (entire fruit, only flesh, or flesh with removal of a smaller or larger portion of the skin) and method of analysis.

Data on centesimal and mineral composition of the fruit in Brazilian native species are scarce. Such studies might promote the inclusion of such fruits in the human diet. More studies related to this subject will contribute to elucidate the potentials benefits of such fruit consumption to human health. Our results show that the fruit of superior Brazilian genotypes of feijoa represent an important source of essential elements. Since the skin of feijoa fruit is usually discarded, more research is required to assess other minerals and functional compounds in such tissue, to encourage its use to develop new products by the food industry.

\section{Conclusions}

Regardless of genotype, the skin tissue had higher values of crude fibre, and the flesh tissue had higher values of crude protein and crude fat, without a substantial difference between these tissues for dry matter. With the exception of 'Nonante', the ash content was higher in the skin than in the flesh (especially in 'Helena', with ash content $\sim 4.5$ higher in the skin than in the flesh). 'Alcantara' and accession 2316 had the highest crude protein contents in the flesh tissue, accession 2316 had the highest content of crude fat in the flesh, Nonante had the highest content of crude fiber in the flesh and Helena had the highest content of crude fiber in the skin. In general, feijoa fruit represent an important source of minerals, especially of $\mathrm{P}$ and $\mathrm{N}$ in the flesh, and of $\mathrm{K}$ and $\mathrm{Fe}$ in the skin and flesh tissues. 'Alcântara' had high contents of Ca, $\mathrm{Fe}, \mathrm{Cu}$ and $\mathrm{Mn}$ in the skin and flesh, and high contents of $\mathrm{N}$ and $\mathrm{P}$ in the skin.

\section{Acknowledgements}

To Conselho Nacional de Desenvolvimento Científico e Tecnológico (CNPq, grant number 301595/2013-5), for financial support; and to Empresa de Pesquisa Agropecuária e Extensão Rural de Santa Catarina (Epagri), Experimental Station of São Joaquim, for supplying feijoa fruits. 


\section{References}

ALVES, A.D.; ALVES, M.S.O.; FERNANDES, T.O.; NAVES, R.V.; NAVES, M.G.V. Caracterização física e química, fenólicos totais e atividade antioxidante da polpa e resíduo de gabiroba. Revista Brasileira de Fruticultura, Jaboticabal, v.35, n.3, p.837-844, 2013.

AMARANTE, C.V.T. do; SOUZA, A.G. de; BENINCA, T.D.T.; STEFFENS, C.A. Fruit quality in Brazilian genotypes of feijoa at harvest and after storage. Pesquisa Agropecuária Brasileira, Brasília, DF, v.52, n.9, p.734742, 2017a.

AMARANTE, C.V.T. do; SOUZA, A.G. de; BENINCA, T.D.T.; STEFFENS, C.A. Phenolic content and antioxidant activity of the fruit in Brazilian genotypes of feijoa. Pesquisa Agropecuária Brasileira, Brasília, DF, v.52, n.12, p.1223-1230, $2017 b$.

AMARANTE, C.V.T. do; STEFFENS, C.A.; BENINCA, T.D.T.; HACKBARTH, C. SANTOS, K.L. Qualidade e potencial de conservação pós-colheita de frutos em cultivares brasileiras de goiaba-serrana. Revista Brasileira de Fruticultura, Jaboticabal, v.35, n.4, p.990999, 2013.

AMARANTE, C.V.T. do; STEFFENS, C.A.; DUCROQUET, J.P.H.J.; SASSO, A. Qualidade de goiabaserrana em resposta a temperatura de armazenamento e ao tratamento com 1-metilciclopropeno. Pesquisa Agropecuária Brasileira, Brasília, DF, v.43, n.12, p.1683-1689, 2008.

AOAC - Association Of Official Analytical Chemistry. Official methods of analysis of the Association of Official Analysis Chemistry. Arlington, 1995. 1094 p.

ARIOLI, C.J.; PINTO, F.A.M.F.; ARAUJO, L.; SANTOS, K. dos; CIOTTA, M.N.; PASA, M. da S. (org.). A cultura da goiabeira-serrana. Florianópolis: Epagri, 2018. 215p.

BEYHAN, O.; BOZKURT, M.A.; BOYSAL, S.C. Determination of macro-micro nutrient contents in dried fruit and leaves and some pomological characteristics of selected feijoa genotypes (Feijoa sellowiana Berg) from Sakarya provinces in Turkey. The Journal of Animal and Plant Science, Islamabad, v.21, n.2, p.251-255, 2011.

BLIGH, E.G.; DYER, W.J. A rapid method of total lipid extraction and purification. Canadian Journal of Biochemistry and Physiology, Ottawa, v.37, n.8, p.911917, 1959.
HIRSCH, G.E.; FACCO, E.M.P.; RODRIGUES, D.B.; VIZZOTTO, M.; EMANUELLI, T. Caracterização físicoquímica de variedades de amora-preta da região Sul do Brasil. Ciência Rural, Santa Maria, v.42, n.5, p.942-947, 2012.

IGNAT, I.; VOLF, I.; POPA, V.I. A critical review of methods for characterization of pholyphenolic compounds in fruits and vegetables. Food Chemistry, London, v.126, n.4, p.1821-1835, 2011.

KINUPP, V.F.; BARROS, I.B.I. Teores de proteína e minerais de espécies nativas, potenciais hortaliças e frutas. Ciência e Tecnologia de Alimentos, Campinas, v.28, n.4, p.846-857, 2008.

LETERME, P.; BULDGEN, A.; ESTRADA, F.; LONDONO, A.M. Mineral content of tropical fruit and unconventional foods of the Andes and the rain forest of Colombia. Food Chemistry, London, v.95, n.4, p.644652, 2006.

MARQUES, A.; CHICAYBAN, G.; ARAUJO, M.T.; MANHÃES, L.R.T.; SABAA-SRUR, A.U.O. Composição centesimal e mineral de casca e polpa de manga (Mangifera indica L.) cv. Tommy Atkins. Revista Brasileira de Fruticultura, Jaboticabal, v.32, n.4, p.1206-1210, 2010.

MONFORTE, M.T.; LANUZZA, F.; MONDELLO, F.; NACCARI, C.; PERGOLIZZI, S.; GALATI, E.M. Phytochemical compositon and gastroprotective effect of Feijoa sellowiana Berg. fruit from Sicily. Journal of Coastal Life Medicine, Hainan Province, v.2, n.1, p.1421, 2014.

ROMERO-RODRIGUEZ, M.A.; VAZQUEZ-ODERIZ, M.L.; LOPEZ-HERNANDEZ, J.; SIMAL-LOZANO, J. Composition of babaco, feijoa, passion-fruit and tamarillo produced in Galicia (NW Spain). Food Chemistry, London, v.49, n.3, p.251-255, 1994.

SANTOS, M.B. dos; CARDOSO, R.L.; FONSECA, A.A.O.; CONCEIÇÃO, M.N. Caracterização e qualidade de frutos de umbu-cajá (Spondias tuberosa X S. mombin) provenientes do recôncavo Sul da Bahia. Revista Brasileira de Fruticultura, Jaboticabal, v.32, n.4, p.10891097, 2010.

SAS UNIVERSITY. Statistical analyses system. Cary, 2017. 
SOERJOMATARAM, I.; OOMEND, D.; LEMMENS, V.; OENEMA, A.; BENETOU, V.; TRICHOPOULOU, A.; GOEBERGH, J.W.; BARENDREGT, J.; VRIES, E. Increased consumption of fruit and vegetables and future cancer incidence in selected European countries. European Journal of Cancer, Villejuif, v.46, n.14, p.2563-2580, 2010.

STORCK, C.R.; NUNES, G.L.; OLIVEIRA, B.B.; BASSO, C. Folhas, talos, cascas e sementes vegetais: composição nutricional, aproveitamento na alimentação e análise sensorial de preparação. Ciência Rural, Santa Maria, v.43, n.3, p.537-543, 2013.

TEDESCO, M.J.; GIANELLO, C.; BISSANI, C.A.; BOHNEN, H.; VOLKWEISS, S.J. Análise do solo, plantas e outros materiais. 2.ed. Porto Alegre: Departamento de Solos - UFRGS, 1995. 174 p.
VALLILO, M.I.; MORENO, P.R.H.; OLIVEIRA, E. de; LAMARDO, L.C.A.; GARBELOTTI, M.L. Composição química dos frutos de Campomanesia xantocarpa Berg-Myrtaceae. Ciência e Tecnologia de Alimentos, Campinas, v. 28, p. 231-237, 2008. Supl.

VAN SOEST, P.J. Limiting factors in plant residues of low biodegradability. Agriculture and Environment, Beijing, v.6, n.1/2, p.135-143, 1981.

VELHO, A.C.; AMARANTE, C.V.T. do; ARGENTA, L.C.; STEFFENS, C.A. Influência da temperatura de armazenamento na qualidade pós-colheita de goiabasserranas. Revista Brasileira de Fruticultura, Jaboticabal, v.33, n.1, p.14-20, 2011.

WESTON, R.J. Bioactive products from fruit of the feijoa (Feijoa sellowiana, Myrtaceae): A review. Food Chemistry, London, v.121, n.1, p.923-926, 2010. 